\title{
原発不明肺門縦隔リンパ節癌の検討
}

\author{
三好健太郎 $1 \cdot$ 奥村典仁 1 古角祐司郎 1 . \\ 松岡智章 1 亀山耕太郎 1 ・中川達雄 1
}

要旨一一目的．肺門縦隔リンパ節のみに癌を認める症例（原発不明肺門縦隔リンパ節癌）の報告が散見される．転移 癌としては良好な予後を示した症例があるが, 頻度は稀でありその病態は明らかにされていない. 当科で経験した原発 不明肺門縦隔リンパ節癌について検討を行った。方法. 当科で過去 20 年間に経験した原発不明肺門縦隔リンパ節癌 8 例について臨床像を明らかにし，病態，治療法について検討した．結果．単一リンパ節のみに病巣が存在するもの (SS 例）が 4 例, 複数のリンパ節に存在するもの（MS 例）が 3 例, 単一のリンパ節に病巣が存在し悪性胸水を伴うもの (SS + MPE 例) が 1 例であった. SS 例に対しては手術（リンパ節完全切除）のみを，MS 例に対しては生検後放射線化 学療法を, SS + MPE 例ではリンパ節切除後化学療法を行った. SS 例では全例 21〜108 か月の非担癌生存を, MS 例で は全例 1 年以内の癌死 (平均生存期間 9.3 か月) を, SS + MPE 例では化学療法施行後 17 か月の担癌生存を認めた。結 論. 肺門部単一病巣, 完全切除は子後良好因子である可能性があり, 切除可能であれば手術による病巣リンパ節の完全 切除を行うべきであると考えられた。（肺癌. 2007;47:245-250)

索引用語 ——原発不明癌, 肺門縦隔リンパ節, 完全切除

\section{Metastatic Thoracic Lymph Node Carcinoma of Unknown Origin}

\author{
Kentaroh Miyoshi ${ }^{1}$; Norihito Okumura ${ }^{1}$; Yujiro Kokado ${ }^{1}$; \\ Tomoaki Matsuoka ${ }^{1}$; Kotaro Kameyama ${ }^{1}$;atsuo Nakagawa ${ }^{1}$
}

\begin{abstract}
Objective. Metastatic thoracic lymph node carcinoma of unknown origin is rare. Some surgical cases which had better outcome than expected were reported in the literature. However, the reason for this unexpected outcome, the etiology, and preferable treatment are unclear. We present a review of our cases. Methods. In the past 20 years, we encountered 8 cases of thoracic lymph node carcinoma of unknown origin. Here we review the clinical course, treatment, and outcome. Results. Four out of 8 patients had single station lymph node carcinoma (SS). Three patients had multistation lesions (MS). One patient had single station lesion with malignant pleural effusion (SS + MPE). SS cases underwent complete excision of the focal lymph node without additional therapy. MS cases underwent chemotherapy or radiation therapy after biopsy. The SS + MPE case received excision of the focal lymph node with additional chemotherapy. All patients in the SS group had long day survival without carcinoma bearing (21-108 months). All patients in the MS group died due to cancer within 1 year (mean survival time: 9.3 months). The SS + MPE patient survived 17 months with carcinoma. Conclusion. A single hilar lesion and complete excision may lead to a good outcome. Thoracic lymph node lesions should be surgically excised if complete excision is possible. (JJLC. 2007;47:
\end{abstract} 245-250)

KEY WORDS — Metastatic carcinoma of unknown origin, Thoracic lymph node, Complete excision

1倉敷中央病院呼吸器外科.

別刷請求先：三好健太郎，倉敷中央病院呼吸器外科， $=710-8602$ 岡山県倉敷市美和 1-1-1.

1Department of Thoracic Surgery, Kurashiki Central Hospital, Japan.
Reprints: Kentaroh Miyoshi, Department of Thoracic Surgery, Kurashiki Central Hospital, 1-1-1 Miwa, Kurashiki, Okayama 7108602, Japan

Received January 10, 2007; accepted March 13, 2007.

(C) 2007 The Japan Lung Cancer Society 


\section{はじめに}

肺門縦隔リンパ節のみに癌を認め原発巣が不明である 奇異な症例（原発不明肺門縦隔リンパ節癌）を認めるこ とがある．通常のリンパ節転移をきたした悪性疾患とし ては矛盾するような良好な経過をとった報告例が散見さ れて抢り，本腫瘍の発症機転や適切な治療法については 様々な議論がある。しかし肺門縦隔リンパ節癌の報告例 はいまだ少なく詳細は不明である，肺門縦隔リンパ節は 肺癌転移の好発部位であるため, 通常進行肺癌として化 学療法, 放射線療法を含めた集学的治療を行うことが多 く, 手術単独での治療例の報告は少ない. 当科で経験し た手術単独での治療例を含む原発不明肺門縦隔リンパ節 癌 8 例について臨床的検討を行い, その病態，治療法に ついて過去の報告例の検討も加えて考察を行ったので報 告する.

\section{対象と方法}

当科で過去 20 年間に経験した, 肺門または縦隔リンパ 節にて病理組織検查上癌を確認されたにもかかわらず, 全経過にわたり他臓器に画像上癌腫を確認できなかった 症例 8 例を対象とした．性別はすべて男性で，平均年齢 は 66.1 歳（53〜83 歳）であり，いずれも悪性腫瘍の既往 はなかった. 8 例中 6 例は無症状であり健診での胸部異 常影を契機に発見した。また 1 例は湿疹, 汎血球減少, 1 例は浮腫, 満月様顔貌, 高 ACTH (adrenocorticotropic hormone) 血症などの腫瘍随伴症状を契機に発見した. 発 症形式としては病巣が単一のリンパ節に限局しているも の (single station：SS 例) 4 例, 複数のリンパ節に存在す るもの (multistation：MS 例) 3 例，病巣リンパ節が単一 で悪性胸水を伴うもの（single station + malignant pleural effusion：SS+MPE 例) 1 例があった. 8 例中 6 例に 術前腫瘍マーカーの上昇を認めた（Table 1)。術前に $\mathrm{CT}$, 気管支鏡検查, 上部下部消化器内視鏡検査により全
身検索を行い他病巣がないことを確認した. 術後は $3 〜 6$ か月ごとにCTで再発巣および原発病巣の検索を行っ た. 腫瘍の発症形式, 治療内容, 組織型, 予後について 検討した。

\section{結 果}

治療経過を Table 2 に示す. SS 例では手術による病巣 リンパ節切除を行った。いずれの症例もリンパ節は周囲 組織との癒着はあるものの被膜外一の浸潤は認められ ず，完全切除を施行し得た。な打切除は周囲結合組織を 含めて目標リンパ節の切除を行い，近傍に腫大したリン パ節があれば追加切除した. SS 例 4 例中 3 例において胸 腔鏡下手術を適用した。開胸術を行った症例 6 では病巣 リンパ節が右肺上葉内部に抢よんで扔り核出が困難で あったため肺葉切除を要した.MS 例では, 2 例で縦隔鏡 下生検, 1 例で胸臆鏡下生検を行い, SS + MPE 例では胸 腔鏡下リンパ節切除を行った。組織型は, 腺癌 3 例, 大 細胞癌 2 例, 神経内分泌癌 2 例, 扁平上皮癌 1 例と多彩 であった。いずれも低分化で免疫組織化学検査上一定の 傾向はなく, 原発臟器の推定は困難であった。また各症 例間に組織学的共通点を認めなかった. SS 例では全例で 術後補助療法は行わず，経過観察のみを行った．MS 例 3 例のうち Case 1 は放射線治療のみ（縦隔へ $50 \mathrm{~Gy}$ の照 射）を, Case 3 は放射線化学療法（縦隔から両側肺門へ の $50 \mathrm{~Gy}$ の照射および carboplatin + docetaxel 3 コース) を, Case 7 は化学療法のみ（carboplatin + CPT-11 を 4 コース）を行った．MS+MPE 例ではリンパ節の切除を 行った後, 化学療法 (carboplatin + paclitaxel 3 コース) を 行った. 切除単独を行った SS 例では術後 21〜108 か月 (平均 48.8 か月) で全例非担癌生存中である。一方, MS 例では全例術後 1 年以内で癌死した平均生存期間は 9.3 か月であった，再発形式は，Case 1 で骨，脳，肝転移へ の多発転移, Case 3 で脳転移, Case 7 で脳, 肝転移であっ た. SS + MPE 例では化学療法施行後 17 か月の現在, 胸

Table 1. Patient Characteristics

\begin{tabular}{|c|c|c|c|c|c|}
\hline \multirow{2}{*}{ Case } & \multirow{2}{*}{ Age } & \multirow{2}{*}{ Gender } & \multicolumn{2}{|c|}{ Lymph node involvement } & \multirow{2}{*}{ Tumor markers } \\
\hline & & & Location & Characteristics & \\
\hline 1 & 66 & Male & Rt. upper mediastinum & MS & TPA, SLX \\
\hline 2 & 83 & Male & Rt. interlober site & $\mathrm{SS}(35 \mathrm{~mm})$ & CEA, CYFRA \\
\hline 3 & 53 & Male & Upper mediastinum-bil. hilum & MS & - \\
\hline 4 & 54 & Male & Rt. hilum & $\mathrm{SS}(18 \mathrm{~mm})$ & ProGRP, ACTH \\
\hline 5 & 68 & Male & Lt. hilum & $\mathrm{SS}(26 \mathrm{~mm})$ & CEA, SLX \\
\hline 6 & 70 & Male & Rt. hilum & $\mathrm{SS}(40 \mathrm{~mm})$ & - \\
\hline 7 & 73 & Male & Upper mediastinum-bil. hilum & MS & CEA, SLX, NSE, ProGRP \\
\hline 8 & 62 & Male & Rt. hilum & $\mathrm{SS}(35 \mathrm{~mm})+\mathrm{MPE}$ & SLX \\
\hline
\end{tabular}

MS: Multistation, SS: Single station, MPE: Malignant pleural effusion. 
Table 2. Treatments and Clinical Courses

\begin{tabular}{|c|c|c|c|c|c|}
\hline Case & Operation & $\begin{array}{l}\text { Pathological } \\
\text { diagnosis }\end{array}$ & $\begin{array}{c}\text { Postoperative } \\
\text { therapy }\end{array}$ & $\begin{array}{c}\text { Follow-up } \\
\text { (months) }\end{array}$ & Status \\
\hline 1 & $\begin{array}{c}\text { Biopsy } \\
\text { (mediastinoscopy) }\end{array}$ & $\begin{array}{l}\text { Large cell } \\
\text { carcinoma }\end{array}$ & $\mathrm{RT}$ & 8 & $\begin{array}{c}\text { Dead } \\
\text { (Multiple metastasis) }\end{array}$ \\
\hline 2 & $\begin{array}{l}\text { Complete excision } \\
\text { (VATS) }\end{array}$ & $\begin{array}{l}\text { Squamous cell } \\
\text { carcinoma }\end{array}$ & None & 108 & $\begin{array}{c}\text { Alive } \\
\text { (No recurrence) }\end{array}$ \\
\hline 3 & $\begin{array}{l}\text { Biopsy } \\
\text { (VATS) }\end{array}$ & Adenocarcinoma & $\mathrm{RT}+\mathrm{CT}$ & 12 & $\begin{array}{c}\text { Dead } \\
\text { (Brain metastasis) }\end{array}$ \\
\hline 4 & $\begin{array}{l}\text { Complete excision } \\
\text { (VATS) }\end{array}$ & $\begin{array}{l}\text { Neuroendocrine } \\
\text { carcinoma }\end{array}$ & None & 35 & $\begin{array}{c}\text { Alive } \\
\text { (No recurrence) }\end{array}$ \\
\hline 5 & $\begin{array}{l}\text { Complete excision } \\
\text { (VATS) }\end{array}$ & $\begin{array}{l}\text { Large cell } \\
\text { carcinoma }\end{array}$ & None & 31 & $\begin{array}{c}\text { Alive } \\
\text { (No recurrence) }\end{array}$ \\
\hline 6 & $\begin{array}{l}\text { Complete excision } \\
\text { (thoracotomy) }\end{array}$ & Adenocarcinoma & None & 21 & $\begin{array}{c}\text { Alive } \\
\text { (No recurrence) }\end{array}$ \\
\hline 7 & $\begin{array}{c}\text { Biopsy } \\
\text { (mediastinoscopy) }\end{array}$ & $\begin{array}{l}\text { Neuroendocrine } \\
\text { carcinoma }\end{array}$ & $\mathrm{CT}$ & 8 & $\begin{array}{c}\text { Dead } \\
\text { (Brain and liver metastasis) }\end{array}$ \\
\hline 8 & $\begin{array}{l}\text { Biopsy } \\
\text { (VATS) }\end{array}$ & Adenocarcinoma & $\mathrm{CT}$ & 17 & $\begin{array}{c}\text { Alive } \\
\text { (Stable MPE) }\end{array}$ \\
\hline
\end{tabular}

VATS: Video-assisted thoracic surgery, RT: Radiation therapy, CT: Chemotherapy, MPE: Malignant pleural effusion.

膜播種を有しながらも担癌生存中である.

\section{考 察}

原発不明癌（転移性悪性腫瘍を極めて疑う画像, 組織 所見をとるにもかかわらず他蔵器に癌腫を認めない症 例) は, 文献上 60 歳代を中心とした男性に多く, 骨, 肺, 肝に好発し, 腺癌の組織像を呈するものが多い.1 リンパ 節も原発不明癌の好発部位のひとつとされているが, 頸 部発生が多いといわれている. ${ }^{2}$ 肺門縦隔リンパ節発生 例については近年報告例が散見されるものの少ない. 本 稿執筆時に過去の文献を検索したところ本邦での誌上報 告数は 62 例あったが, まとまった数の症例を報告したも のはない.

自験例 8 例をあわせた本邦の原発不明肺門縦隔リンパ 節癌 70 例の内訳をみると，性別では男性 57 例 (81\%)， 女性 13 例（19\%）と男性に多く，組織型では腺癌 29 例 (41\%), 小細胞癌 13 例 (19\%), 大細胞癌 12 例 (17\%), 扁平上皮癌 11 例 $(16 \%)$, その他 5 例 $(7 \%)$ と腺癌が多 い. なおいずれの組織型についても低分化型と記載され ているものがほとんどでありこれも本腫瘍の特徵である と考えられる。発生箇所は縦隔のみが 30 例 $(43 \%)$, 肺 門のみが 22 例 $(31 \%)$, 縦隔肺門におよぶものが 18 例 (26\%) であり, SS 例は 40 例 $(57 \%), \mathrm{MS}$ 例は 30 例 (43\%) であった.

原発不明癌全体では 5 年生存率が $5.1 〜 9 \%$ と報告さ れており一般的に予後不良とされている一方, $1,3,4$ リン パ節発生例は頸部リンパ節例を中心に切除後良好な予後 をとった報告例を複数認める. ${ }^{5}$ 肺門縦隔リンパ節発生 例においても同様に良好な経過をとったとする報告が多
い. 本邦 70 例の原発不明肺門縦隔リンパ節癌治療報告例 のうち, 観察期間について記載のなかった 3 例を除く 67 例（平均観察期間 26.2 か月）について生存分析を行った ところ, 1 年生存率 $89.4 \%, 2$ 年生存率 $80.0 \%$ と $\mathrm{pN} 2$ 肺癌 手術例の一般的な経過よりも良い印象であった（Figure 1). 他藏器発生の癌からの転移にしては不完全切除であ るにもかかわらず良好な経過をとることが多いため，原 発不明リンパ節癌の病態については以下に示すような 種々の可能性が考えられる.

(1)過去に手術歴があった場合, 原発腫瘍が偶然切除され てしまった。

(2)原発腫瘍が非常に小さいため画像上あるいは病理組織 学的に検索できておらず，原発腫瘍に増大傾向がないか あるいは自然消退した.

(3)原発腫瘍が非常に小さいため画像上あるいは病理組織 学的に検索できておらず, 放射線療法, 化学療法により 原発病巣が完全治癒した。

(4)そもそも他臓器に悪性腫瘍はなく, リンパ節内に癌が 発生した.

(1)の仮説については，過去に手術歴があることが前提 となるが，手術歴がなく本仮説では説明がつかない症例 が自験例を含めて存在する。（2)の仮説については，縦隔 リンパ節転移をきたす頻度が最も高い肺癌を含む複数の 癌において自然消失の報告例が過去にあり, 6,7 可能性と してあり得る説である. Kohdono らは経過中に肺内に認 めた小細胞癌が自然消失し, 肺門リンパ節癌のみが増大 をきたした症例を報告している.8 しかし一方で自験例 のみならず極めて予後不良な経過をたどった過去の症例 の中に，全経過中に原発病変が確認されないものもあ 


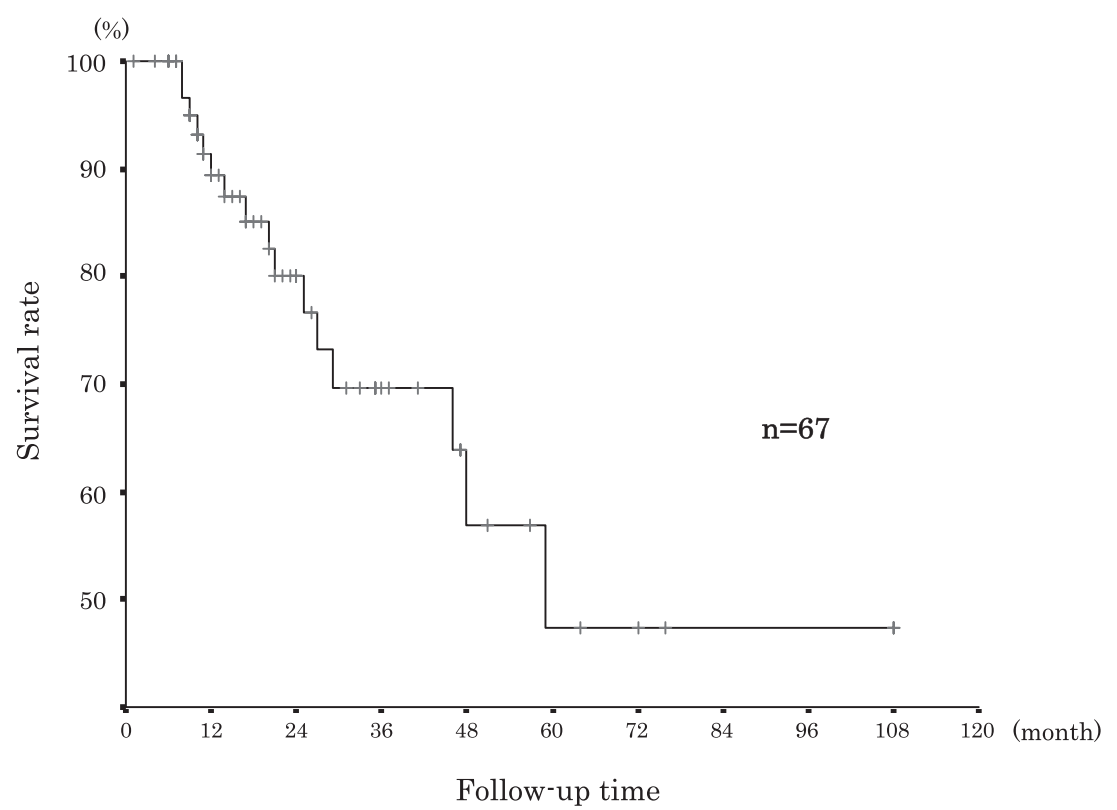

Figure 1. Survival of 67 patients in the past literature.

る. ${ }^{9}$ (3)の仮説については, 切除後に化学療法, 放射線療 法が行われた報告において考察されてきた説である。し かし自験例ではSS 群に対して手術単独治療のみで全例 極めて良好な予後が観察されており，(3)の説に矛盾する 経過をたどる例の存在が示された.

切除を行った場合予後良好, 経過観察を行っても原発 病巣と考えられる病変が出現しないといった臨床所見 は，本疾患がリンパ節に発生した癌であるとすると矛盾 なく理解できるため, これまでにも(4)の仮説を提唱する 報告がある，真崎らは，縦隔には気管支上皮や胸腺など の鰓弓原性臓器があり, 鰓弓原性臓器にはリンパ上皮腫, Warthin 腫瘍, Mikulicz 症候群, 胸腺腫など上皮とリン パ組織とが一体となった腫瘍が多く発生している，また 原発不明リンパ節癌の好発部位である頸部はやはり鰓弓 原性臓器で形成されている，などを根拠に(4)の仮説を提 唱している.10 また Riquet らは正常の腺組織が迷入し た肺門リンパ節の組織を提示し，このようなリンパ節の 存在はリンパ節原発の癌の存在を示唆するとしてい る. ${ }^{11}$ 正常の上皮組織が迷入するリンパ節の存在につい ては腋窝リンパ節において複数の報告例があり, 12 同様 の現象が肺門縦隔リンパ節にも起こる可能性は否定でき ない，それらに加えて手術単独治療で良好な予後を認め た自験例に扔ける結果も，本疾患がリンパ節原発の癌で あるという説を臨床的に支持するものであると考えられ る.

しかし病理組織学的に本疾患の病因を立証することは 困難である。原発不明肺門縦隔リンパ節癌の組織像は,
過去の報告例，自験例ともに多彩で，共通していえるこ とはいずれも極めて低分化な癌であるということであ る。肺原発か否かを評価するべくTTF1，CK7/CK20 などの免疫組織化学検査を行い検討している報告もある が，いずれも特定臟器に特徽的な結果は得られていな い. 10,13 自験例においても形態より推定される原発臟器 に特異的な免疫染色を行い評価したが，上皮に特異的な 種々の抗体に不規則に陽性所見を呈するのみで原発臟器 の推定は困難であった。またリンパ節原発癌という概念 がこれまでにないため，これを直接，組織形態や免疫組 織化学検查により診断することも理論上不可能である. 他蔵器に癌を認めず，リンパ節内部のみに正常上皮組織 およびこれを発生母地とする癌を認める症例があれば, リンパ節発生の仮説を強く裏づけることが可能であろう が，我々が検索した限りこのような報告はなく，自験例 においてもこのような病理組織所見は確認できなかっ た.リンパ節に癌が発生したかのような臨床像を呈する ものの，今のところこの説は推定の域を超えるものでは なく, 発生機序の解明については今後のさらなる症例の 蓄積と検討を要する。

今回の我々の検討では, 肺門部発生の SS 例に対して 完全切除を行った場合, 術後全身療法を行わなくても良 好な予後が得られた一方, 生検のみを行い放射線化学療 法を行った MS 例は極めて予後不良であった。本疾患に おいて肺門部単一病巣は予後良好因子である可能性が推 測された．本邦の予後の記載があった 67 例について SS 例 (39 例) と MS 例 (28 例) に分類し, 生存率の比較 


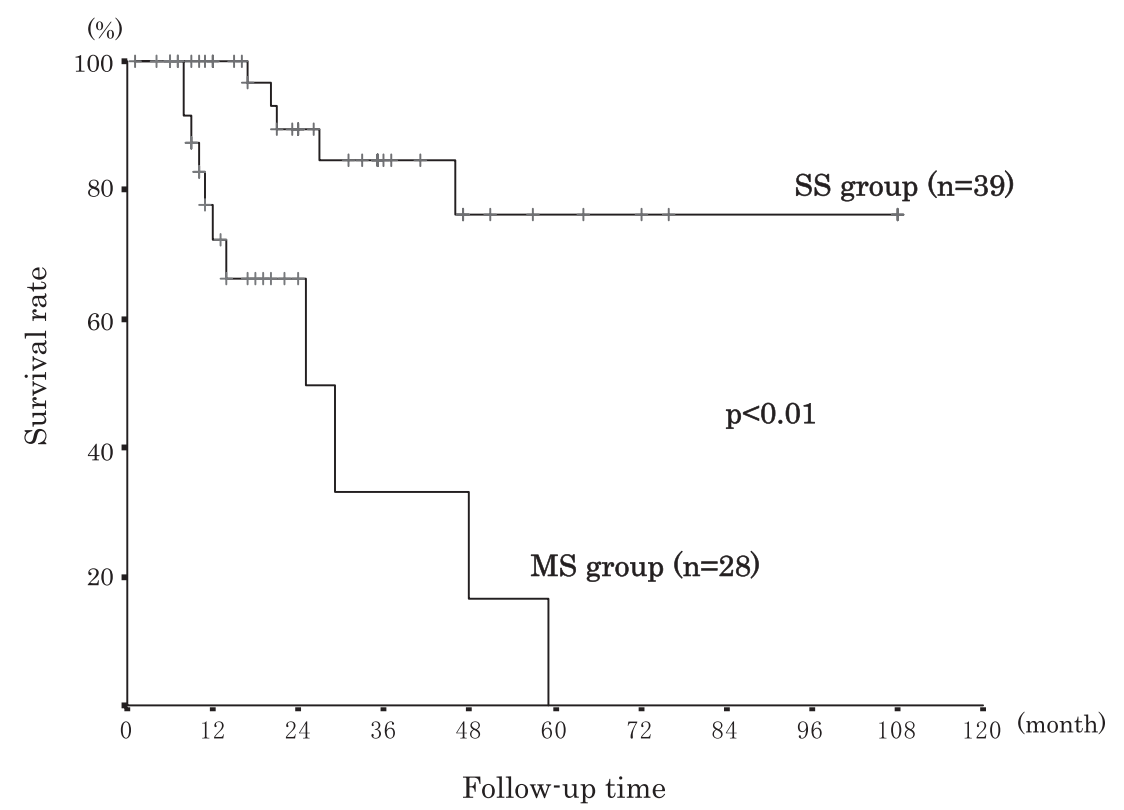

Figure 2. Survival of single station (SS) group or multistation (MS) group in the literature $(n=67)$.

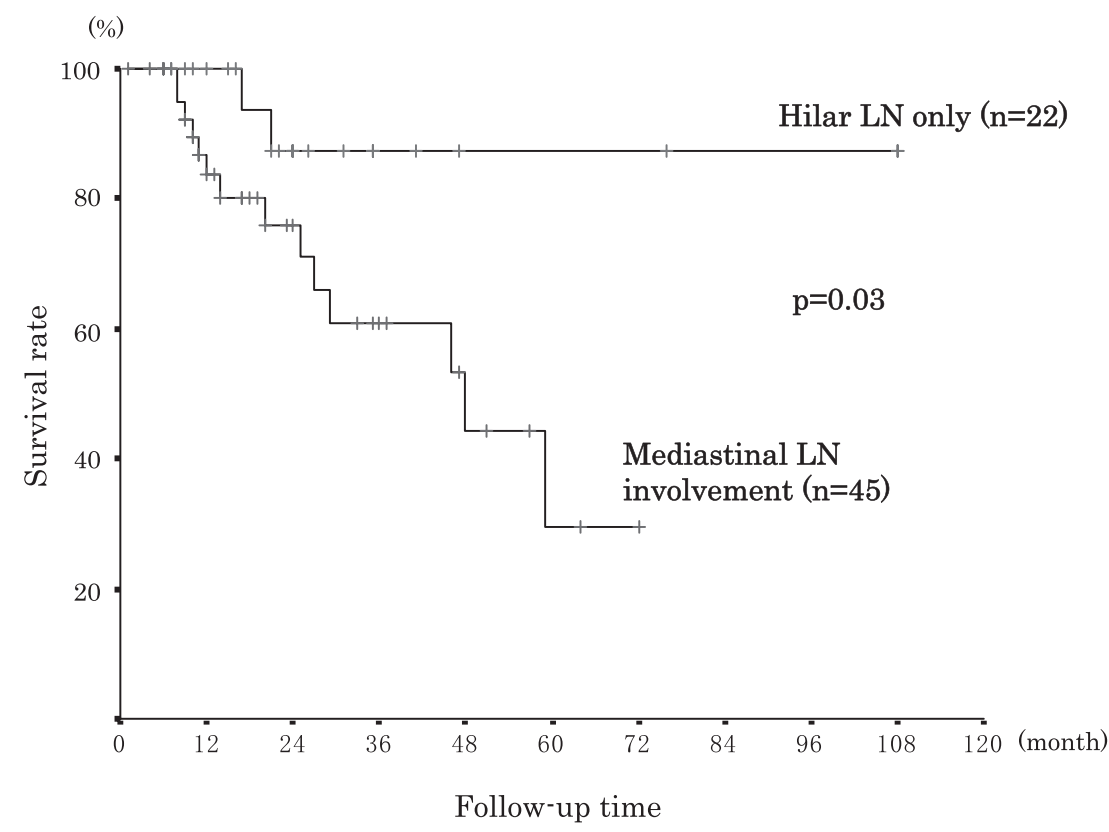

Figure 3. Survival of patients in relation to mediastinal lymph nodes (LN) involvement $(n=67)$.

（log-rank 検定による）を行ってみると，明らかにSS 群の予後が優れていた (Figure 2)。 また病巣が肺門に限 局するもの 22 例と縦隔におよぶもの 45 例に分類して同 様に比較したところ，肺門部型の症例は縦隔におよぶ場 合に比べると予後が良好である可能性が示唆された (Figure 3). 過去の例からも同様の傾向が予想され, 特に
肺門部に限局する症例, また SS 例に関しては, 生検では なく切除を行うのが望ましいと考えられた.

手術による完全切除を推奨する報告が多いものの, 切 除の際腫瘍のみではなく周囲のリンパ節の系統的郭清を 要するのか, また MS 例に対しても切除を行えば良好な 予後が期待できるのかなどの問題については議論の残る 
ところである. 前者については肉眼的に転移が疑われな かったリンパ節に組織学的に転移を認めた報告例もある ため, 14,15 周囲リンパ節の郭清を加えるのが望ましいか もしれない. また後者については, 縦隔 MS 例に対して 両側縦隔郭清を行い良好な予後を得た報告例があり, 16 我々が予後不良と考えた縦隔発生例, MS 例についても 手術による切除が有効である可能性もある。しかし手術 侵襲が大きくなる一方, 治療効果が不明であるためこの ような治療例の報告は少ない. 放射線, 化学療法の有用 性がそしいこともあり，進行例と思われる MS 例に対す る手術の有効性については今後の検討課題であると思わ れる。

\section{結 語}

我々が経験した原発不明肺門縦隔リンパ節癌 8 例を検 討した. 肺門部単一リンパ節のみに病巣が存在した 4 例 すべてにおいて手術単独で良好な予後を得た，一方，多 発例では極めて予後不良な経過をたどった.これはリン パ節に癌が原発したとする仮説に矛盾しない臨床経過で あった．特に肺門部に限局した単一病変，完全切除は予 後良好因子である可能性が高く, 切除可能な症例は病巣 リンパ節の完全切除を目的とした手術を早期に行うこと が望ましいと考えられた.

\section{REFERENCES}

1. Holmes FF, Fouts TL. Metastatic cancer of unknown primary site. Cancer. 1970;26:816-820.

2. Greager JA, Wood D, Das Gupta TK. Metastatic cancer from an undetermined primary site. J Surg Oncol. 1983;23: 73-76.

3. Smith PE, Krementz ET, Chapman W. Metastatic cancer without a detectable primary site. Am J Surg. 1967; 113:633-637.

4. Altman E, Cadman E. An analysis of 1539 patients with cancer of unknown primary site. Cancer. 1986;57:120-124.
5. Medini E, Medini AM, Lee CK, et al. The management of metastatic squamous cell carcinoma in cervical lymph nodes from an unknown primary. Am J Clin Oncol. 1998; 21:121-125.

6. Kappauf H, Gallmeier WM, Wunsch PH, et al. Complete spontaneous remission in a patient with metastatic nonsmall-cell lung cancer. Case report, review of the literature, and discussion of possible biological pathways involved. Ann Oncol. 1997:8:1031-1039.

7. Cafferata MA, Chiaramondia M, Monetti F, et al. Complete spontaneous remission of non-small-cell lung cancer: a case report. Lung Cancer. 2004;45:263-266.

8. Kohdono S, Ishida T, Fukuyama Y, et al. Lymph node cancer of the mediastinal or hilar region with an unknown primary site. J Surg Oncol. 1995;58:196-200.

9. 大野喜代志, 佐々木義明. 中縦隔にびまん性に拡がる, 発 生母地不明の腺癌症例. 日呼吸会誌. 2001;39:524-527.

10. 真崎義隆, 五味淵誠, 田中茂夫, 他. 原発巣不明肺門縦隔 リンパ節癌の本邦報告例の検討. 胸部外科. 1997;50:743747.

11. Riquet M, Badoual C, le Pimpec BF, et al. Metastatic thoracic lymph node carcinoma with unknown primary site. Ann Thorac Surg. 2003;75:244-249.

12. Fisher CJ, Hill S, Millis RR. Benign lymph node inclusions mimicking metastatic carcinoma. J Clin Pathol. 1994;47: 245-247.

13. Yoshino N, Yamauchi S, Hino M, et al. Metastatic thoracic lymph node carcinoma of unknown origin on which we performed two kinds of immunohistochemical examinations. Ann Thorac Cardiovasc Surg. 2006;12:283-286.

14. 松毛真一, 細川誉至雄, 佐藤一人, 他. 縦隔リンパ節転移 を初発症状とした large cell neuroendocrine carcinoma の 1 例. 日胸. 1999;58:668-672.

15. 山本一道, 上野孝男, 池田敏和, 他. 高 CEA 血症にて発 見された原発巣不明癌に対し右上葉スリーブ切除および 縦隔リンパ節郭清を行った 1 例. 胸部外科. 2000;53:605607.

16. 守尾 篤, 宮元秀昭, 泉浩, 他. 原発不明縦隔リンパ 節転移腺癌の 1 治験例一本邦報告例 21 例の検討一. 肺 癌. 2001;41:73-78. 